\section{Effect of Astragalus tenellus on Sheep ${ }^{1}$}

\section{LYNN F. JAMES}

Poisonous Plant Research Laboratory, Veterinary Science Research Division, Agriculture Research Service, U. S. Department of Agriculture, Logan, Utah.

\section{Highlight}

Feeding trials involving Astragalus tenellus demonstrated that this plant is not toxic to sheep.

It is estimated that there are as many as 300 species of Astragalus in North America (Kingsbury, 1964). Approximately 13 of these produce locowced poisoning in livestock (Kingsbury, 1964 and Oehme et al., 1968). Some, such as $A$. miser, produce acute poisoning (Williams and Binns, 1967), and others accumulate selenium and may be involved in the etiology of selenium intoxication (Rosenfeld and Beath, 1964). Many are known to be nontoxic while others remain to be tested for toxicity to animals. Astragalus tenellus has been suspected of bcing toxic in some areas and there is one report of it being cytotoxic in in vitro experiments (Muni et al., 1967). This experiment was conducted to test the toxicity of $A$. tenellus to sheep.

\section{Materials and Methods}

Astragalus tenellus was collected for sheep feeding experiments near Price, Utah. It was air-dricd, ground in a hammer mill and stored at $5 \mathrm{C}$ until used. Some plant to be fed green was collected in the same area. It was brought to the laboratory, refrigerated, and fed as quickly thereafter as possible.

The stage of growth when the plant was collected and feeding schedule is shown in Table 1. All plant matter was fed via stomach tube.

All shecp were treated for internal parasites before beginning the experiment. The sheep fed the green plant were fasted for 12 hours before the first feeding. The daily dosage of 1,816 grams was divided into two equal parts and half was fed in the morning and half in the evening. This amount $(908$

\footnotetext{
${ }^{1}$ Received September 30, 1970; accepted for publication October 8, 1970.
}

Table 1. The schedule for the feeding of Astragalus tenellus to sheep.

\begin{tabular}{clcc}
\hline $\begin{array}{c}\text { Number of } \\
\text { sheep fed }\end{array}$ & \multicolumn{1}{c}{$\begin{array}{c}\text { Stage of } \\
\text { plant growth }\end{array}$} & $\begin{array}{c}\text { Amount of plant } \\
\text { fed/day (g) }\end{array}$ & $\begin{array}{c}\text { Length of time } \\
\text { fed (days) }\end{array}$ \\
\hline 3 & Flower (dried) & 680 & 32 \\
3 & Flower (dried) & 454 & 32 \\
3 & Seed (dricd) & $112-454$ & 38 \\
3 & Control & & 32 \\
2 & Flower (green) & 1816 & 3 \\
2 & Pre-flower (green) & 1816 & 3 \\
\hline
\end{tabular}

grams) is near the maximum that can be fed by this method in one feeding.

Blood was collected before the first feeding and weekly thereafter from the sheep given the dried plant. The blood was analyzed for: red blood cell count, white blood cell count, hemoglobin, packed ccll volume, differential white cell count, blood urea nitrogen, lactic dehydrogenase (LDH), serum glutamic oxaloacetic transaminase (SGOT), blood glucose, and red blood cell cholinesterase. Blood was collected from the sheep fed the green plant for serum glutamic oxaloacetic transaminase determination before the first and after the last feeding. Feed and water consumption was measured daily on those recciving the dried plant. Tissue samples were taken for histological examination.

\section{Results and Discussion}

All sheep fed the $A$. tenellus re mained normal in appearance throughout the experiment.

When dried locoweed, A. pubentissimus, $A$. lentiginosus or $O$. sericeus is fed, signs of poisoning appear before the end of a 30-day feeding period. The signs of intoxication include depression, staggering gait, rough coat, emaciation, lack of muscular coordination, and nervousness (Marsh, 1909). Animals given $A$. miser at levels similar to those in this experiment would have been expected to die of acute intoxication.

There were no deviations from normal in any of the blood constituents measured in any of the sheep. Changes in $\mathrm{LDH}^{2}$ and SGOT (James et al., 1970) are very pronounced in locoweed poisoning and acute Astragalus poison-

${ }^{2}$ Johnson, A. E., and Lynn F. James. Unpublished manuscript with the Veterinary Science Research Division, Agriculture Research Service, Logan, Utah. ing (Williams and Binns, 1967). There was no change in feed or water intake.

Histological examination failed to reveal any deviation from normal.

Field observations on two ranges revealed that cattle readily grazed this plant even in the presence of an abundance of grass. There was some evidence that deer also graze this plant.

\section{Literature Cited}

James, Lynn F., Kent R. Van Kampen, and A. Earl Johnson. 1970. Physiopathologic changes in locoweed poisoning of livestock. Am. J. Vet. Res. 31:663-672.

Kingsbury, John M. 1964. Poisonous Plants of the United States and Canada. Prentice Hall Inc. Englewood Cliffs, New Jersey.

Muni, I. A., W. H. Bhatti, L. J. ScherMEISTER, AND M. C. Vincent. 1967. Cytotoxicity of North Dakota plants. I. In vitro studies. J. Pharm. Sci. $56: 50-54$.

Marsh, C. D. 1909. The locoweed disease of the plains. U.S. Dep. Agr., Bureau of Animal Industry Bulletin 112.

Oehme, Fredrick W., Wayne $E$. Bailie, and Lloyd C. Hulbert. 1968. Astragalus mollissimus (locoweed) toxicosis of horses in Western Kansas. J. Am. Vet. Med. Assoc. 152:271-278.

Rosenfeld, Irene, and Orville A. Beath. 1964. Selenium. Academic Press, N. Y.

Williams, M. Coburn, and Wayne Binns. 1967. Toxicity of Astragalus miser Dougl. var oblongifolius (Rydb.) Cronq. Weeds 15:359-362.

Longmont Seed Co.

We Buy \& Sell Western Range Grass \& Legume Seeds

CONFRONT US with your RANGE

PROBLEMS: phone: $303+776-1320$ LONGMONT, COLORADO 80501 